KEMAS 13 (2) (2017) 277-285
Jurnal Kesehatan Masyarakat

\title{
SUPPORT OF FAMILY MEMBER, PUBLIC FIGURE, AND HEALTH ATTENDANT TO PSN BEHAVIOR AND RELATED FACTORS
}

\author{
Rouhdy Rangga ${ }^{1 凶}$, Nguyen Tra Giang ${ }^{2}$, Muhammad Azinar ${ }^{1}$, Oktia Woro Kasmini Handayani ${ }^{1}$ \\ ${ }^{1}$ Public Health Science Major, State University of Semarang \\ ${ }^{2}$ Hong Bang International University, Vietnam
}

\section{Article Info \\ Article History: \\ Submitted Oktober 2016 \\ Accepted November 2017 \\ Published November 2017 \\ Keywords: \\ Behavior; mosquito's \\ breeding placeeradica- \\ tion; dengue; family \\ DOI \\ http://dx.doi.org/10.15294/ \\ kemas.v13i2.12112}

\begin{abstract}
Abstrct
The eradication of mosquito's breeding place (PSN) is the most effective efforts to prevent the increasing prevalence of DHF in Demak which is $43 \%$ of its area is endemic. This study aims to determine the factors related to PSN behavior by family members. This is an observational analytic study with cross sectional approach using 210 samples divided into 3 groups of respondents (father, mother, child) with purposive sampling technique. Data were obtained through questionnaire based on interview results and analyzed by chi square. The results of the research on the father respondents showed that there was a relationship between the support of family members $(\mathrm{p}=0.001)$, support of community leaders $(\mathrm{p}=0.007)$, and support of health attentand $(\mathrm{p}=0.005)$ with PSN behavior. In mother respondents was found that the support of family members $(p=0.006)$ and support of health officer $(\mathrm{p}=0.009)$ correlated with PSN behavior. In the child respondents was found that the support of family members $(\mathrm{p}=0.000)$, support of community leaders $(\mathrm{p}=0.007)$, and support of health officer $(\mathrm{p}=0.009)$ correlated with PSN behavior. It was concluded that the support of family members and support of health attendant was related to the behavior of PSN in all groups of respondents, and support of community leaders related to PSN behavior to the respondents of father and child.
\end{abstract}

\section{Introduction}

Dengue Hemorrhagic Fever (DHF) is an infectious disease oftenly causing a plaque and even deceased. It caused by dengue virus which is Arthropod-Borne Virus, genus Flavivirus, family Flaviviridae. DHF is transferred through mosquito bite from genus Aedes, particularly Aedes aegypti or Aedes albopictus. DHF can emerge for whole year and able to infect all group age. This disease is related with environment and community behavior (Kemenkes RI, 2015)

Global DHF prevalence is increasing every year. The number of cases in US, South
East Asia and West Pasific had surpassed 1.2 millions cases in 2008 and increase up to more than 2.3 millions cases in 2010. In 2013, there are 2.35 millions cases had been reported from US, where 37,687 cases are severe. In Indonesia, 100,347 DHF cases (39.8/100,000 population) with mortality number 907 persons (CFR $0.9 \%$ ) is reported in 2014 (Kemenkes RI, 2015). Central Java Province is DHF endemic region with Incident Rate (IR) in 2015 is $47.9 / 100,000$ population increase from 2014 (32.95/100,000 population) while DHF CRF in 2015 was $1.56 \%$ increase from $2014(1.44 \%)$ and 2013

\footnotetext{
$\triangle$ Correspondence Address:

F5 Building, Faculty of Sport Science, Universitas Negeri Semarang

Email : rouhdy@gmail.com
} 
(1.21\%) (Dinkes Jateng, 2016). It can be known that $43 \%$ of Demak Region area was DHF endemic, increase from 2015 (37\%). The DHF IR on Demak Region in 2016 is $76.7 / 100,000$ population with DHF CFR 2.5\%, while Larva Free Number (Angka Bebas Jentik/ABJ) $79.25 \%$.

Demak District is DHF endemic region with highest CFR compare to other 13 districts. Within last one year there are 87 cases of DHF and 3 of it are deceased (ABJ 31\%). One of subdistrict with highest DHF IR is Subdistrict Mangunjiwan with positive dispersion since it is highly populated area and is recorded as endemic area. There are 11 cases of 7,312 population on Subdistrict Mangunjiwan and 3 cases of it is found out at Community Association (Rukun Warga/RW) 06 (1,104 population) with $\mathrm{ABJ}$ only $23.3 \%$, so that RW 06 and Subdistrict Mangunjiwan is very prone in case of DHF infection compare to other area. While National Strategic Plan target of DHF incident is IR $\leq 51 / 100,000$ population, CFR < $1 \%$, and $A B J \geq 95 \%$ (Kemenkes RI, 2015).

The height of Incident Rate and Case Fatality Rate for DHF are caused by unstable climate and quite high rainfall in rainy season provide supported condition for Aedes aegipty mosquito reproduction. Along with not maximal of Mosquito Nest Eradication (Pemberantasan Sarang Nyamuk/PSN) activity among the community then resulting extraordinary incident (Kejadian Luar Biasa/ $\mathrm{KLB}$ ) of DHF. Moreover, it is found out that dengue vector density in Central Java still surpasses the limit of infection and Aedes aegipty has become resistant to insectiside active substance (Sayono, 2016). Therefore the effort to minimize and controll DHF that most effective and efficient nowadays is by PSN activity.

There are several factors related with PSN activity based on previous researches, like education, past experience of DHF infected, knowledge, attitude, information access, has been coached, and health attendant support by PSN activity (Listyorini, 2016; Mohamad, 2014). This is aligned with previous research on Subdistrict Mangunjiwan Demak indicating that knowledge and attitude have relation with PSN (Azam, 2016). Other research explain that PSN behavior has significant relation with DHF incident (Respati, 2007). On the other side, family is the closest and main place where behavior is formed, maintained and developed. The involvement of all family members in the effort to prevent the disease has larger effect than one active family member, an finally the community health can be increased. The most ideal family form is core family (traditional nuclear) consists of the father, mother and children living in one house.

Based on above, the researcher is interested to analyze further regarding the factors related with PSN behavior in preventing DHF by family members (father, mother, and children) on RW06 Subdistrict Mangunjiwan, Demak where as far as researcher knowledge, there has not been any similar research which analyzed similar factors on core family members consist of Father, Mother and Children on one research.

\section{Method}

Research used is observational analysis with cross sectional design. Analyzed variables consist of education, work status, DHF experience, knowledge, attitude, information access, family member support, public figure support and health attendant support. This research is conducted in 2017 at RW 06, Subdistrict Mangunjiwan, District Demak, Region Demak. The population is all family registerred as RW 06 community which is 216 family. Sample is family with core members consist of father, mother, and children on early and end teenage group (12-25 years old) as research criteria. Sample taken is 210 respondents from 70 families taken based on purposive sampling technique with detail as follow : 70 fathers, 70 mothers and 70 children respondents. Data collection technique is conducted by interview and observation with questionaire guided that has been validity and reliability tested. Data analysis conducted are univariate and bivariate by chi square.

\section{Result And Discussion}

On father respondents, of total 70 subjects mostly are 36-45 years old (64.3\%), in term of education mostly does not graduate Junior High School (74.3\%), work status mostly working (94.3\%), mostly does not has DHF infected experience (92.9\%). Father respondent 
Table 1. Description of Research Subject Characteristic ( $\mathrm{n}=210)$

\begin{tabular}{|c|c|c|c|c|c|c|}
\hline \multirow{3}{*}{ Respondent Characteristic } & \multicolumn{6}{|c|}{ Respondent Group } \\
\hline & \multicolumn{2}{|l|}{ Father } & \multicolumn{2}{|l|}{ Mother } & \multicolumn{2}{|l|}{ Children } \\
\hline & $\mathrm{f}(\mathrm{n}=70)$ & $\%$ & $\mathrm{f}(\mathrm{n}=70)$ & $\%$ & $f(n=70)$ & $\%$ \\
\hline \multicolumn{7}{|l|}{ Age (years) } \\
\hline $46-55$ & 21 & 30 & 5 & 7.1 & - & - \\
\hline $36-45$ & 45 & 64.3 & 43 & 61.4 & - & - \\
\hline $26-35$ & 4 & 5.7 & 22 & 31.4 & - & - \\
\hline $17-25$ & - & - & - & - & 34 & 48.6 \\
\hline $12-16$ & - & - & - & - & 36 & 51.4 \\
\hline \multicolumn{7}{|l|}{ Sex } \\
\hline Male & 70 & 100 & - & - & 23 & 32.9 \\
\hline Female & - & - & 70 & 100 & 47 & 67.1 \\
\hline \multicolumn{7}{|l|}{ Education } \\
\hline Junior High Graduate & 18 & 25.7 & 46 & 65.7 & - & - \\
\hline Junior High Not Graduate & 52 & 74.3 & 24 & 34.3 & - & - \\
\hline Educated & - & - & - & - & 62 & 88.6 \\
\hline Uneducated & - & - & - & - & 8 & 11.4 \\
\hline \multicolumn{7}{|l|}{ Work Status } \\
\hline Work & 66 & 94.3 & 5 & 7.1 & - & - \\
\hline Does not work & 4 & 5.7 & 65 & 92.9 & - & - \\
\hline \multicolumn{7}{|l|}{ DHF Experience } \\
\hline Has & 5 & 7.1 & 5 & 7.1 & 5 & 7.1 \\
\hline Does not has & 65 & 92.9 & 65 & 92.9 & 65 & 92.9 \\
\hline \multicolumn{7}{|l|}{ Knowledge } \\
\hline Good & 37 & 52.9 & 35 & 50 & 36 & 51.4 \\
\hline Fair & 29 & 41.4 & 33 & 47.1 & 34 & 48.6 \\
\hline Poor & 4 & 5.7 & 2 & 2.9 & 0 & 0 \\
\hline \multicolumn{7}{|l|}{ Attitude } \\
\hline Good & 39 & 55.7 & 37 & 52.9 & 34 & 48.6 \\
\hline Poor & 31 & 44.3 & 33 & 47.1 & 36 & 51.4 \\
\hline \multicolumn{7}{|l|}{ Information Access } \\
\hline Easy & 50 & 71.4 & 42 & 60 & 41 & 58.6 \\
\hline Difficult & 20 & 28.6 & 28 & 40 & 29 & 41.4 \\
\hline \multicolumn{7}{|l|}{ Family Member Support } \\
\hline More Support & 40 & 57.1 & 49 & 70 & 53 & 75.7 \\
\hline Less Support & 30 & 42.9 & 21 & 30 & 17 & 24.3 \\
\hline \multicolumn{7}{|l|}{ Public Figure Support } \\
\hline More Support & 35 & 50 & 36 & 51.4 & 40 & 57.1 \\
\hline Less Support & 35 & 50 & 34 & 48.6 & 30 & 42.9 \\
\hline \multicolumn{7}{|l|}{ Health Attendant Support } \\
\hline More Support & 38 & 54.3 & 41 & 58.6 & 37 & 52.9 \\
\hline Less Support & 32 & 45.7 & 29 & 41.4 & 33 & 47.1 \\
\hline \multicolumn{7}{|l|}{ PSN Behavior } \\
\hline Better & 44 & 62.9 & 45 & 64.3 & 44 & 62.9 \\
\hline Worse & 26 & 37.1 & 25 & 35.7 & 26 & 37.1 \\
\hline
\end{tabular}


Rouhdy Rangga, et al / Support Of Family Member, Public Figure, and Health Attendant

Table 2. Relation of Various Factors with PSN Behavior on Father Respondents

\begin{tabular}{|c|c|c|c|c|c|c|c|}
\hline \multirow{3}{*}{$\begin{array}{l}\text { Factors } \\
\text { (Variables) }\end{array}$} & \multicolumn{3}{|c|}{ PSN Behavior } & \multirow{3}{*}{$P$ Value } & \multirow{3}{*}{ OR } & \multirow{2}{*}{\multicolumn{2}{|c|}{$95 \% \mathrm{CI}$}} \\
\hline & \multirow{2}{*}{$\begin{array}{l}\text { Good } \\
\text { n (\%) } \\
\end{array}$} & \multirow{2}{*}{$\begin{array}{l}\text { Poor } \\
\text { n (\%) }\end{array}$} & \multirow{2}{*}{$\begin{array}{c}\text { Total } \\
\text { N (\%) } \\
\end{array}$} & & & & \\
\hline & & & & & & Lower & Upper \\
\hline \multicolumn{8}{|l|}{ Education } \\
\hline Junior High School Graduate & $5(7.1)$ & $13(18.6)$ & $18(25.7)$ & 0.502 & 1.761 & 0.546 & 5.679 \\
\hline Junior High School Does not Graduate & $21(30)$ & $31(44.3)$ & $52(74.3)$ & & & & \\
\hline \multicolumn{8}{|l|}{ Work } \\
\hline Work & $24(34.3)$ & $42(60)$ & $66(94.3)$ & 0.624 & 1.750 & 0.231 & 13.233 \\
\hline Does not work & $2(2.9)$ & $2(2.9)$ & $4(5.7)$ & & & & \\
\hline \multicolumn{8}{|l|}{ DHF Infected Experience } \\
\hline Has & $2(2.9)$ & $3(4.3)$ & $5(7.1)$ & 1.000 & 0.878 & 0.137 & 5.633 \\
\hline Does Not Has & $24(34.3)$ & $41(58.6)$ & $65(92.9)$ & & & & \\
\hline \multicolumn{8}{|l|}{ Knowledge } \\
\hline Good & $14(20)$ & $23(32.9)$ & $37(52.9)$ & Reference & & & \\
\hline Fair & $11(15.7)$ & $18(25.7)$ & $29(41.4)$ & 1.000 & 1.004 & 0.369 & 2.735 \\
\hline Poor & $1(1.4)$ & $3(4.3)$ & $4(5.7)$ & 1.000 & 0.548 & 0.052 & 5.792 \\
\hline \multicolumn{8}{|l|}{ Attitude } \\
\hline Good & $13(18.6)$ & $26(37.1)$ & $39(55.7)$ & 0.624 & 1.444 & 0.544 & 3.832 \\
\hline Poor & $13(18.6)$ & $18(25.7)$ & $31(44.3)$ & & & & \\
\hline \multicolumn{8}{|l|}{ Information Access } \\
\hline Easy & $18(25.7)$ & $32(45.7)$ & $50(71.4)$ & 0.969 & 1.185 & 0.409 & 3.437 \\
\hline Difficult & $8(11.4)$ & $12(17.1)$ & $20(28.6)$ & & & & \\
\hline \multicolumn{8}{|l|}{ Family Members Support } \\
\hline More Support & $8(11.4)$ & $32(45.7)$ & $40(57.1)$ & 0.001 & 6.000 & 2.069 & 17.401 \\
\hline Less Support & $18(25.7)$ & $12(17.1)$ & $30(42.9)$ & & & & \\
\hline \multicolumn{8}{|l|}{ Public Figure Support } \\
\hline More Support & $7(10)$ & $28(40)$ & $35(50)$ & 0.007 & 4.750 & 1.642 & 13.740 \\
\hline Less Support & $19(27.1)$ & $16(22.9)$ & $35(50)$ & & & & \\
\hline \multicolumn{8}{|l|}{ Health Attendant Support } \\
\hline More Support & $8(11.4)$ & $30(42.9)$ & $38(54.3)$ & 0.005 & 4.821 & 1.692 & 13.736 \\
\hline Less Support & $18(25.7)$ & $14(20)$ & $32(45.7)$ & & & & \\
\hline
\end{tabular}

having good knowledge is $52.9 \%$, better attitude $55.7 \%$, easy information access $71.4 \%$, get family support $57.1 \%$, get public figure support $50 \%$, get health attendant support $54.3 \%$ and has better PSN behavior 62.9\%. Based on bivariate analysis can be seen that factors related with PSN behavior on father respondent are family member support $(\mathrm{p}=0.001)$, public figure support $(\mathrm{p}=0.007)$, and health attendant support $(\mathrm{p}=0.005)$.

On mother respondents, of total 70 subjects mostly are $36-45$ years old (61.4\%), in term of education mostly Junior High School graduate $(65.7 \%)$, work status mostly does not work (92.9\%), mostly does not has DHF infected experience (92.9\%). Mother respondent having good knowledge is $50 \%$, better attitude $52.9 \%$, easy information access $60 \%$, get family support $70 \%$, get public figure support $51.4 \%$, get health attendant support $58.6 \%$ and has better PSN behavior $64.3 \%$. Based on bivariate analysis can be seen that factors related with PSN behavior on mother respondent are family member support $(p=0,006)$ and health attendant support $(\mathrm{p}=0,009)$.

On children respondents, of total 70 subjects mostly are $12-16$ years old (51.4\%), mostly is female (67.1\%), in term of education mostly edudated (88.6\%), mostly does not has DHF infected experience (92.9\%). Children 
respondent having good knowledge is $51.4 \%$, better attitude $48.6 \%$, easy information access $58.6 \%$, get family support $75.7 \%$, get public figure support $57.1 \%$, get health attendant support $52.9 \%$ and has better PSN behavior $62.9 \%$. Based on bivariate analysis can be seen that factors related with PSN behavior on Children respondent are family member support $(\mathrm{p}=0.000)$, public figure support $(\mathrm{p}=0.007)$ and health attendant support $(\mathrm{p}=0.009)$.

Statistic test result shown there is no relation between education with PSN behavior whether on father, mother or children respondent. This is aligned with Monintja (2015) stating there is not significant relation between education and PSN activity on Subdistrict Malalayang I City of Manado ( $\mathrm{p}=0.114)$, yet it is not aligned with Liza (2015) stating that education is related with participation of DHF prevention on District Kuta Alam Banda Aceh ( $p=0.05)$. The unaligned result of this research result can be explained through Theory of Planned Behavior (TPB) which is an expansion of Theory of Reasoned Action (TRA). This theory explains that education of father, mother and children respondent can not affect the behavior directly yet it is affected by the intention first, while the intention is affected by attitude, subjective norm and perception control (Notoatmodjo, 2014).

Based on statistic test can be seen that

Table 3. Relation of Various Factors with PSN Behavior on Mother Respondents

\begin{tabular}{|c|c|c|c|c|c|c|c|}
\hline \multirow{3}{*}{$\begin{array}{l}\text { Factors } \\
\text { (Variables) }\end{array}$} & \multicolumn{3}{|c|}{ PSN Behavior } & \multirow{3}{*}{$P$ Value } & \multirow{3}{*}{ OR } & \multirow{2}{*}{\multicolumn{2}{|c|}{$95 \% \mathrm{CI}$}} \\
\hline & \multirow{2}{*}{$\begin{array}{c}\text { Good } \\
\text { n (\%) }\end{array}$} & \multirow{2}{*}{$\begin{array}{l}\text { Poor } \\
\text { n (\%) }\end{array}$} & \multirow{2}{*}{$\frac{\text { Total }}{\text { N (\%) }}$} & & & & \\
\hline & & & & & & Lower & Upper \\
\hline \multicolumn{8}{|l|}{ Education } \\
\hline Junior High School Graduate & $13(18.6)$ & $33(47.1)$ & $46(65.7)$ & 0,124 & 2,538 & 0,910 & 7,080 \\
\hline Junior High School Does not Graduate & $12(17.1)$ & $12(17.1)$ & $24(34.3)$ & & & & \\
\hline \multicolumn{8}{|l|}{ Work } \\
\hline Work & $2(2.9)$ & $3(4.3)$ & $5(7.1)$ & 1,000 & 0,821 & 0,128 & 5,277 \\
\hline Does not work & $23(32.9)$ & $42(60)$ & $65(92.9)$ & & & & \\
\hline \multicolumn{8}{|l|}{ DHF Infected Experience } \\
\hline Has & $2(2.9)$ & $3(4.3)$ & $5(7.1)$ & 1,000 & 0,821 & 0,128 & 5,277 \\
\hline Does Not Has & $23(32.9)$ & $42(60)$ & $65(92.9)$ & & & & \\
\hline \multicolumn{8}{|l|}{ Knowledge } \\
\hline Good & $10(14.3)$ & $25(35.7)$ & $35(50)$ & Reference & & & \\
\hline Fair & $14(20)$ & $19(27.1)$ & $33(47.1)$ & 0.347 & 1.842 & 0.673 & 5.043 \\
\hline Poor & $1(1.4)$ & $1(1.4)$ & $2(2.9)$ & 0.512 & 2.500 & 0.142 & 43.968 \\
\hline \multicolumn{8}{|l|}{ Attitude } \\
\hline Good & $14(20)$ & $23(32.9)$ & $37(52.9)$ & 0.886 & 0.821 & 0.308 & 2.194 \\
\hline Poor & $11(15.7)$ & $22(31.4)$ & $33(47.1)$ & & & & \\
\hline \multicolumn{8}{|l|}{ Information Access } \\
\hline Easy & $14(20)$ & $28(40)$ & $42(60)$ & 0.799 & 1.294 & 0.479 & 3.495 \\
\hline Difficult & $11(15.7)$ & $17(24.3)$ & $28(40)$ & & & & \\
\hline \multicolumn{8}{|l|}{ Family Members Support } \\
\hline More Support & $12(17.1)$ & $37(52.9)$ & $49(70)$ & 0.006 & 5.010 & 1.676 & 14.981 \\
\hline Less Support & $13(18.6)$ & $8(11.4)$ & $21(30)$ & & & & \\
\hline \multicolumn{8}{|l|}{ Public Figure Support } \\
\hline More Support & $9(12.9)$ & $27(38.6)$ & $36(51.4)$ & 0.094 & 2.667 & 0.970 & 7.331 \\
\hline Less Support & $16(22.9)$ & $18(25.7)$ & $34(48.6)$ & & & & \\
\hline \multicolumn{8}{|l|}{ Health Attendant Support } \\
\hline More Support & $9(12.9)$ & $32(45.7)$ & $41(58.6)$ & 0.009 & 4.376 & 1.546 & 12.386 \\
\hline Less Support & $16(22.9)$ & $13(18.6)$ & $29(41.4)$ & & & & \\
\hline
\end{tabular}


Rouhdy Rangga, et al / Support Of Family Member, Public Figure, and Health Attendant

Table 4. Relation of Various Factors with PSN Behavior on Children Respondents

\begin{tabular}{|c|c|c|c|c|c|c|c|}
\hline \multirow{3}{*}{$\begin{array}{l}\text { Factors } \\
\text { (Variables) }\end{array}$} & \multicolumn{3}{|c|}{ PSN Behavior } & \multirow{3}{*}{$P$ Value } & \multirow{3}{*}{ OR } & \multirow{2}{*}{\multicolumn{2}{|c|}{ 95\%CI }} \\
\hline & \multirow{2}{*}{$\begin{array}{l}\text { Good } \\
\text { n (\%) }\end{array}$} & \multirow{2}{*}{$\frac{\text { Poor }}{\text { n (\%) }}$} & \multirow{2}{*}{$\begin{array}{l}\text { Total } \\
\text { N (\%) }\end{array}$} & & & & \\
\hline & & & & & & Lower & Upper \\
\hline \multicolumn{8}{|l|}{ Education } \\
\hline Educated & $23(32.9)$ & $39(55.7)$ & $62(88.6)$ & 1.000 & 1.017 & 0.222 & 4.658 \\
\hline Uneducated & $3(4.3)$ & $5(7.1)$ & $8(11.4)$ & & & & \\
\hline \multicolumn{8}{|c|}{ DHF Infected Experience } \\
\hline Has & $3(4.3)$ & $2(2.9)$ & $5(7.1)$ & 0.353 & 0.365 & 0.057 & 2.345 \\
\hline Does Not Has & $23(32.9)$ & $42(60)$ & $65(92.9)$ & & & & \\
\hline \multicolumn{8}{|l|}{ Knowledge } \\
\hline Good & $13(18.6)$ & $23(32.9)$ & $36(51.4)$ & 1.000 & 1.095 & 0.415 & 2.889 \\
\hline Fair & $13(18.6)$ & $21(30)$ & $34(48.6)$ & & & & \\
\hline \multicolumn{8}{|l|}{ Attitude } \\
\hline Good & $10(14.3)$ & $24(34.3)$ & $34(48.6)$ & 0.292 & 1.920 & 0.715 & 5.157 \\
\hline Poor & $16(22.9)$ & $20(28.6)$ & $36(51.4)$ & & & & \\
\hline \multicolumn{8}{|c|}{ Information Access } \\
\hline Easy & $13(18.6)$ & $28(40)$ & $41(58.6)$ & 0.385 & 1.750 & 0.654 & 4.682 \\
\hline Difficult & $13(18.6)$ & $16(22.9)$ & $29(41.4)$ & & & & \\
\hline \multicolumn{8}{|c|}{ Family Members Support } \\
\hline More Support & $13(18.6)$ & $40(57.1)$ & $53(75.7)$ & 0.000 & 10.000 & 2.771 & 36.093 \\
\hline Less Support & $13(18.6)$ & $4(5.7)$ & $17(24.3)$ & & & & \\
\hline \multicolumn{8}{|c|}{ Public Figure Support } \\
\hline More Support & $9(12.9)$ & $31(44.3)$ & $40(57.1)$ & 0.007 & 4.504 & 1.599 & 12.686 \\
\hline Less Support & $17(24.3)$ & $13(18.6)$ & $30(42.9)$ & & & & \\
\hline \multicolumn{8}{|c|}{ Health Attendant Support } \\
\hline More Support & $8(11.4)$ & $29(41.4)$ & $37(52.9)$ & 0.009 & 4.350 & 1.537 & 12.310 \\
\hline Less Support & $18(25.7)$ & $15(21.4)$ & $33(47.1)$ & & & & \\
\hline
\end{tabular}

there is no relation between work status with PSN behavior whether on father or mother respondent. This is aligned with Maulida (2016) stating that there is no relation between job with DHF prevention behavior on Pakijangan Brebes ( $\mathrm{p}=0.189)$ so does with Monintja (2015) stating there is not significant relation between job with PSN activity on community of Subdistrict Malalayang I City of Menado $(\mathrm{p}=0.086)$, yet this is not aligned with Wong (2015) stating that there is relation between job with DHF prevention behavior on Malaysia community $(p=0.029)$ and Hasim (2013) stating there is significant relation between job with DHF PSN activity on house wife mother on Subdistrict Surau Gadang City of Padang $(\mathrm{p}=0.03)$. The unalignment can be explained by Transtheoritical Model Behavior Theory stating that work status can not affect the behavior directly yet through several stages. It can be explained that the respondent in the beginning does not has intention to do PSN activity (precontemplation stage), then start to think to do it (contemplation stage), then occurs a strong will and intention to do PSN activity (preparation stage), by then the behavior is actualized though it has not consistant (action stage), therefore the PSN activity become a habbit routinely and sustainably conducted maintenance stage) (Priyoto, 2014)

Statistic test on all respondent's group (father, mother and children) show that there is no relation between DHF infected experience with PSN behavior. This is aligned with Mohamad (2014) stating that DHF infected experience does not related with PSN behavior on DHF risk region in Malaysia. The unalignment of the result can be explained 
through Protection Motivation Theory (PMT) stating that DHF infected experience owned by father, mother, and children respondent can not affect PSN behavior directly, but by the intention to behave first (Priyoto, 2014).

The statistic test on father, mother, and children respondent indicates there is not relation between knowledge and PSN behavior. This is aligned with Thakolwiboon (2013) stating that the knowledge is not related with DHF prevention behavior of community in Thaluang Thailand $(\mathrm{p}=0.862)$ also as found out in a study by Mohamad (2014) stating that knowledge is not related with PSN behavior on DHF risk region in Malaysia, yet this is not aligned with result by Chandren (2015) stating there is relation between knowledge with DHF prevention activity of Orang Asli in Semenanjung Malaysia $(\mathrm{p}=0.015)$ and the result of research by Castro (2013) stating that there is relation between knowledge with DHF prevention activity in La Lisa Havana Kuba. The unalignment can be explained through Theory of Reasoned Action (TRA) saying that knowledge can not affect the behavior directly yet it is affected by intention first, while the intention it self is affected by subjective attitude and norm (Notoatmodjo, 2014).

Based on statistic test result on all respondent group (father, mother, and children) can be seen that there is no relation between attitude with PSN behavior. This is aligned with Bahtiar (2012) saing that there is no relation between attitude and DHF control practice on Puskesmas Tawalu work region City of Tasikmalaya $(\mathrm{p}=0.177)$ and the result from Thakolwiboon (2013) stating that attitude is not related with DHF prevention behavior of community in District Thaluang Thailand $(p=0.457)$, yet this is not aligned with Listyorini (2016) stating that attitude is related with PSN behavior of community on Subdistrict Karangjati Blora Regency ( $\mathrm{p}=0.001)$ and study by Liza (2015) stating that attitude is related with DHF prevention participating on District Kuta Alam Banda Aceh. The unalignment can be explained through Transtheoritical Model Behavior Theory saying that attitude can not direcly affect behavior but through severage stages first which are precontemplation, contemplation, preparation, action and maintenance (Priyoto, 2014).

Statistic test indicate that information access is not related with PSN behavior whether on father, mother, or children respondent. This is not aligned with Mohamad (2014) stating that information access is related with PSN behavior on DHF risk region in Malaysia and Nuryanti (2013) saying that information access is related with DHF PSN behavior of community on Subdistrict Karangjati Blora Regency $(\mathrm{p}=0,001)$. The unalignment can be explained by Protection Motivation Theory (PMT) stating that access to information source is not directly yet through cognitive media process first. Based on the theory can be explained that PSN behavior can be formed with the occurance of intention to behave emerge after the fulfillment of components as follow: selfefficacy, effectiveness respond, vulnerability and severity. Those attitude components are affected by environment and intrapersonal factors that can be in form of information access to information particulary regarding DHF and PSN activity (Priyoto, 2014).

Statistic test result indicates the relation between family member support with PSN behavior of father, mother, and children respondent. This is aligned with Lawrence Green theory explaining family member support include as reinforcing factor able to support and empower the health behavior like PSN activity, therefore the respondent require example and support from other family member to have good PSN behavior (Notoatmodjo, 2014).

Based on statistic test can be seen there is relation between public figure with PSN behavior of father and children respondent. This is aligned with Zahir (2016) stating that there is relation between public figure support with DHF control practice on community in Swat Pakistan $(\mathrm{p}=0.04)$. The relation between public figure support with PSN behavior on Father respondent is aligned with Precede Model Behavior Theory stated by Lawrence Green. This theory explains that reinforcing factors can be manifested in attitude, behavior and public figure support as reference to the forming of respondent PSN behavior (Notoatmodjo, 2014).

It is different with statistic test result of 
mother respondent stating that public figure support is not related with PSN behavior. This result is aligned with Bahtiar (2012) stating that there is no relation between between public figure support with DHF control practice on Puskesmas Kawalu work region City of Tasikmalaya $(\mathrm{p}=0.177)$. This can be explained by Theory of Planned Behavior (TPB) which is expansion of Theory of Reasoned Action (TRA). This theory explains that public figure motivation or support can not affect the behavior directly but it is affected by the intention first, while the intention is affected by attitude, subjective norm and perception control. Through this theory can be concluded that PSN behavior on mother respondent will be determined by consideration of benefitloss of the activity fist, then a belief of taken behavior will occur, next the self control occur along with perception of consequences that will be occured if the PSN activity is not done (Priyoto, 2014).

Statistic test on all respondent's group (father, mother, and children) indicates there is relation between health attendant support with PSN behavior. This is aligned with Nuryanti (2013) stating that health attendant support is related with DHF PSN behavior of community on Village Karangjati Blora Regency $(\mathrm{p}=0.001$ ). The relation between health attendant support with PSN behavior on all respondent group is aligned with Precede Model Behavior Theory stated by Lawrence Green. This theory explains that support or reinforcing factor can be manifested in attitude, behavior and health attendant support as reference to the occurance of respondent PSN behavior. Sometimes knowledge and ability is not sufficient to form health behavior like PSN activity, therefore respondent need example and support from health attendant to be able to have good PSN behavior (Notoatmodjo, 2014).

\section{Conclusion}

It can be concluded that family members and health attendant support is related with PSN behavior on all respondent group (father, mother, and children), public figure support is related with PSN behavior on father and children respondent. There is not relation between education, work status, DHF infected experience, knowledge, attitude andinformation access with PSN behavior on all respondent group (father, mother, and children). Also there is not relation between public figure support with PSN behavior on Mother respondent. To improve family members role in PSN activity as an effort to prevent DHF infection, it is advised to increase the support between family member, motivation from local public figure and health attendant role, like information sharing (coaching, media, etc) and community empowerment program.

\section{References}

Azam, M., Azinar, M., \& Fibriana, A. I. 2016. Analisis Kebutuhan dan Perancangan "Ronda Jentik" sebagai Model Pemberdayaan Masyarakat dalam Pemberantasan Sarang Nyamuk. Unnes Journal of Public Health, 5(4): 294-305.

Bahtiar, Y. 2012. Hubungan Pengetahuan dan Sikap Tokoh Masyarakat dengan Perannya dalam Pengendalian Demam Berdarah di Wilayah Puskesmas Kawalu Kota Tasikmalaya. Jurnal ASPIRATOR,4(2): 73-84.

Castro, M., Sanchez, L., Perez, S., Sebrango, C., Shkedy, Z., \& Van der Stuyft, P. 2013. The Relationship between Economic Status, Knowledgeon Dengue, Risk Perceptions and Practices. Journal PLOS ONE, 8(12): 1-6.

Chandren, J.R., Wong, L.P., \& AbuBakar, S. 2015. Practices of Dengue Fever Prevention and theAssociated Factors among the Orang Asli inPeninsular Malaysia. Journal PLOS Neglected Tropical Diseases, August 12, 2015: 1-17.

Dinkes Jateng. 2016. Buku Saku Kesehatan Tahun 2015. Semarang: Dinas Kesehatan Provinsi Jawa Tengah.

Hasyim, D.M. 2013.Faktor-faktor yang Berhubungan dengan TindakanPemberantasan Sarang Nyamuk Demam Berdarah Dengue (PSN DBD). Jurnal Kesehatan,4(2): 364-370.

Kemenkes RI. 2015. Profil Kesehatan Indonesia 2014. Jakarta: Kementerian Kesehatan Republik Indonesia.

Listyorini, P.I. 2016. Faktor-faktor yang Mempengaruhi Perilaku Pemberantasan Sarang Nyamuk (PSN) pada Masyarakat Karangjati Kabupaten Blora. Jurnal INFOKES,6(1): 6-15.

Liza, A., Imran., \& Mudatsir. 2015. Hubungan Tingkat Pengetahuan, Pendidikan dan Sikap dengan Partisipasi Ibu Rumah Tangga dalam PencegahanWabah DBDdi Kecamatan Kuta Alam Banda Aceh. Jurnal Kedokteran Syiah Kuala,15(3): 135-141.

Maulida, I., Prastiwi, R.S., \& Hapsari, L.H. 2016. 
Analisis HubunganKarakteristik Kepala Keluarga dengan Perilaku Pencegahan Demam Berdarah di Pakijangan Brebes. Jurnal INFOKES, 6(1): 1-5.

Mohamad, M., Selamat, M.I., \& Ismail, Z. 2014. Factor Associated with Larval Control Practices in a Dengue Outbreak Prone Area. Journal of Enviromental and Public Health, Volume 2014: 1-6.

Moninjta, T.C.N. 2015. Hubungan antara Karakteristik Individu, Pengetahuan dan Sikap dengan Tindakan PSN DBD Masyarakat Kelurahan Malalayang I Kecamatan Malalayang Kota Manado. Jurnal JIKMU, 5(2b): 503-519.

Notoatmodjo, S. 2014. Ilmu Perilaku Kesehatan. Jakarta: Rineka Cipta.

Nuryanti, E. 2013. Perilaku Pemberantasan Sarang Nyamuk di Masyarakat. Jurnal KEMAS, 9(1): 15-23.

Priyoto. 2014. Teori Sikap dan Perilaku dalam Kesehatan: Dilengkapi Contoh Kuesioner. Yogyakarta: Nuha Medika.

Respati, Y. K. \& Keman, S. 2007. Perilaku 3M, Abatisasi dan Keberadaan Jentik AedesHubungannya dengan Kejadian
Demam Berdarah Dengue. Jurnal Kesehatan Lingkungan, 3(2): 107-118.

Sayono \& Nurullita, U. 2016.Situasi Terkini Vektor Dengue (aedes Aegypti) di Jawa Tengah. Jurnal KEMAS, 11(2): 96-105.

Thakolwiboon, S., Benjatikul, N., Sathianvichitr, K., Prapathrangsee, K., Tienmontri, T., Ratanaamonsakul, W., Assantachai, P., \& Homsanit, M. 2013. Factors Associated with Dengue Prevention and Controlin Two Villages in a Central Thai Province:A Retrospective Review. Journal of the Medical Association of Thailand, 96(8): 984:991.

Wong, L.P., Shakir, S.M.M., Atefi, N., \& AbuBakar, S. 2015. Factors Affecting Dengue PreventionPractices: Nationwide Survey of theMalaysian Public. Journal PLOS ONE, April 2: 1-16.

Zahir, A., Ullah, A., Shah, M., \& Mussawar, A. 2016. Community Participation, Dengue Fever Prevention and ControlPractices in Swat, Pakistan.International Journal of $\mathrm{MCH}$ and AIDS, 5(1): 39-45. 